\title{
Surgical treatment of innominate artery and aortic aneurysm: a case report and review of the literature
}

Erdinc Soylu', Leanne Harling ${ }^{1,3^{*}}$, Hutan Ashrafian', Vania Anagnostakou², Dimitris Tassopoulos ${ }^{2}$, Christos Charitos ${ }^{2}$, John Kokotsakis ${ }^{2}$ and Thanos Athanasiou ${ }^{1}$

\begin{abstract}
Innominate artery (IA) aneurysms represent 3\% of all arterial aneurysms. Due to the risk of thromboembolic complications and spontaneous rupture, surgical repair is usually recommended on an early elective basis. We present the case of 81-year-old Caucasian male presenting with atypical anterior chest pain secondary to a large innominate artery aneurysm who underwent successful open surgical repair at our institution. In our experience, open correction via median sternotomy with extension into the right neck provides excellent exposure and facilitates rapid reconstruction with good short and long-term outcomes. Minimally invasive and endovascular approaches provide emerging alternatives to open IA aneurysm repair, however further research is required to better define optimal patient selection criteria and determine the long-term outcomes of these novel therapies.
\end{abstract}

Keywords: Brachiocephalic trunk, Aneurysm, Surgery

\section{Background}

Aneurysms of innominate artery (IA) make up approximately $3 \%$ of all arterial [1] and 3\% of all supra-aortic vessel aneurysms [2]. The majority of IA aneurysms are atherosclerotic in aetiology [3], however alternative causes include syphilis, tuberculosis, Kawasaki's disease, Takayasu's arteritis, Behçets disease, connective tissue disorders and angiosarcoma.

Aneurysms of the IA commonly present secondary to local compression, thrombosis or distal embolization, giving rise to a diverse range of symptoms including dyspnoea, dysphagia, hoarseness, facial and upper limb oedema, chest pain, digital ischaemia, right hemispheric symptoms, amorosis fugax, vertebrobasilar syndrome, and rarely the presence of a pulsatile anterior thoracic mass [4].

Untreated IA aneurysms are liable to rupture, compress nearby viscera or give rise to cerebrovascular embolism [3]. Rupture is the most threatening presentation occurring in approximately $11 \%$ of all patients [5]. The

\footnotetext{
* Correspondence: Leanne.harling@imperial.ac.uk

1 Department of Surgery and Cancer, Imperial College London, London, UK ${ }^{3}$ Department of Surgery and Cancer, Imperial College London, 10th floor QEQM Building, St. Mary's Hospital, Praed Street, London W2 1NY, UK Full list of author information is available at the end of the article
}

risk of rupture is however more likely following trauma or in patients with underlying connective tissue disease [5,6], and early repair by means of open surgery or endovascular therapy is therefore advocated in patients with symptomatic disease, associated aortic arch aneurysms, saccular aneurysms or isolated asymptomatic aneurysms of $>3 \mathrm{~cm}$ diameter [5].

Over the recent years, there has been an increase in the number of reports of endovascular innominate aneurysm repair however the majority of cases are still treated using an open surgical technique via median sternotomy with or without extension to right neck (Table 1).

We present a case of IA aneurysm involving the aortic arch treated via an open approach, and review the current literature on the role of open surgical and minimally invasive interventions for the treatment of IA aneurysms.

\section{Case presentation}

A 81- year- old Caucasian male with hypertension was admitted to our hospital with atypical anterior chest pain. History and physical examination were unremarkable. However, transthoracic echocardiography demonstrated an aneurysm of the ascending aorta $(5.4 \mathrm{~cm})$ with mild aortic regurgitation and an LVEF of $50 \%$. Computerized

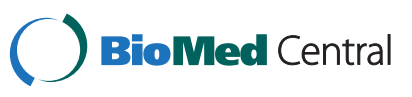


Table 1 Summary of observed short and long-term complications

\begin{tabular}{|c|c|c|c|c|c|c|c|c|c|c|}
\hline \multirow[t]{2}{*}{ Access route } & \multirow[b]{2}{*}{ Study } & \multirow[b]{2}{*}{ Year } & \multirow[b]{2}{*}{$\begin{array}{l}\text { Elective: } \\
\text { Emergency }\end{array}$} & \multirow[b]{2}{*}{$\begin{array}{l}\text { Length } \\
\text { of stay }\end{array}$} & \multicolumn{3}{|c|}{ Short-term outcomes (<30 days) } & \multicolumn{3}{|c|}{ Long-term outcomes ( $>30$ days) } \\
\hline & & & & & Mortality & Morbidity & $\begin{array}{c}\text { Graft } \\
\text { patency }\end{array}$ & Morbidity & $\begin{array}{c}\text { Graft } \\
\text { patency }\end{array}$ & Follow-up \\
\hline \multicolumn{11}{|l|}{ Endovascular } \\
\hline & Angiletta [12] & 2012 & $1: 0$ & - & 0 & - & - & - & Patent & $\begin{array}{l}\text { Alive and developed } \\
\text { an aneurysm of the } \\
\text { right carotid artery } \\
\text { bifurcation at } 96 \\
\text { months }\end{array}$ \\
\hline & Taha [15] & 2010 & $1: 0$ & - & - & - & Patent & - & Patent & - \\
\hline & $\begin{array}{l}\text { Puech-Leao } \\
{[16]}\end{array}$ & 2001 & $1: 0$ & 7 & 0 & - & - & - & Patent & $\begin{array}{l}\text { Alive and symptom } \\
\text { free at } 24 \text { months }\end{array}$ \\
\hline & Park [17] & 2001 & $1: 0$ & - & - & - & Patent & - & Patent & - \\
\hline \multicolumn{11}{|c|}{ Hybrid endovascular and sternotomy } \\
\hline & Mellisano [13] & 2004 & $1: 0$ & 8 & 0 & $\begin{array}{l}\text { Atrial fibrillation, cardiac arrest, } \\
\text { pulmonary effusion }\end{array}$ & Patent & - & - & $\begin{array}{l}\text { Alive and symptom } \\
\text { free at } 3 \text { months }\end{array}$ \\
\hline \multicolumn{11}{|c|}{ Cervical approach } \\
\hline & Takach [18] & 2007 & $1: 0$ & - & 0 & - & - & - & - & - \\
\hline \multicolumn{11}{|c|}{ Partial median sternotomy } \\
\hline & MacLean [19] & 2007 & $1: 0$ & - & - & - & - & - & - & - \\
\hline & Mori [20] & 2004 & 1:0 & - & - & - & - & - & - & - \\
\hline & Lane [21] & 1951 & $1: 0$ & - & 0 & Phrenic nerve damage, fever & - & Muscle atrophy/weakness & - & - \\
\hline \multicolumn{11}{|c|}{ Full median sternotomy } \\
\hline & Constenla [11] & 2012 & $1: 0$ & - & 0 & Respiratory failure, pneumonia & Patent & - & - & $\begin{array}{l}\text { Alive and symptom } \\
\text { free at } 12 \text { months }\end{array}$ \\
\hline & Oswal [22] & 2011 & $1: 0$ & - & 0 & - & - & - & - & $\begin{array}{l}\text { Alive and symptom } \\
\text { free at } 12 \text { months }\end{array}$ \\
\hline & Lu [14] & 2011 & $1: 0$ & - & 0 & - & - & - & - & Alive at 20 months \\
\hline & Yuan [23] & 2009 & $1: 0$ & - & - & Stroke & - & - & - & - \\
\hline & Da Col [24] & 2007 & $1: 0$ & 12 & - & - & Patent & - & - & - \\
\hline & Oruganti [25] & 2006 & $1: 0$ & - & - & - & Patent & - & - & - \\
\hline & Saito [26] & 2005 & $1: 0$ & - & - & - & - & - & - & - \\
\hline & Kieffer [5] & 2001 & $23: 4$ & - & 3 & $\begin{array}{l}\text { Neurological deficits (2), } \\
\text { dysphonia (3), haemorrhage (1), } \\
\text { artficial ventilation (5), multiple } \\
\text { organ failure (2) }\end{array}$ & $\begin{array}{l}\text { Patent (21), } \\
\text { unknown (3) }\end{array}$ & Dysphonia (1), mediastinitis (1) & $\begin{array}{l}\text { Patent } \\
\text { (14), } \\
\text { unknown } \\
\text { (3) }\end{array}$ & $\begin{array}{l}7 \text { deaths (cancer }=3 \text {, } \\
\text { cardiac }=2 \text {, accident }=1 \text {, } \\
\text { unknown }=1 \text { ) during } 85 \\
\text { months (3-194) }\end{array}$ \\
\hline
\end{tabular}


Table 1 Summary of observed short and long-term complications (Continued)

$\begin{array}{llllll}\text { Chiappini [27] } & 2001 & 1: 0 & - & 0 & - \\ \text { Guibaud [28] } & 2001 & 0: 1 & - & 0 & - \\ \text { Najafi [29] } & 1999 & 1: 0 & 6 & - & - \\ \begin{array}{l}\text { Villegas- } \\ \text { Cabello [30] }\end{array} & 1996 & 1: 0 & - & - & - \\ \text { Adkins [31] } & 1993 & 1: 0 & 20 & - & - \\ \text { Bower [3] } & 1991 & 6: 0 & - & 0 & \begin{array}{l}\text { Atelectasis (1), pneumonitis (1), } \\ \text { brain stem infarct (1) }\end{array}\end{array}$

Patent Alive at 6 months

Combined full median sternotomy and cervical approach

$\begin{array}{lccccl}\text { Ketonen [33] } & 1983 & 1: 0 & - & 0 & \begin{array}{l}\text { Wound haematoma of femoral } \\ \text { incision }\end{array} \\ & & 1: 0 & - & 0 & - \\ \text { Murray [34] } & 1971 & 1: 0 & - & 0 & - \\ \text { Zintel [35] } & 1960 & 1: 0 & 14 & 0 & \begin{array}{l}\text { Right arm ischaemia, wound } \\ \text { infection }\end{array}\end{array}$

Subclavian steal syndrome

3 late deaths

(cancer $=1$, stroke $=1$,

vasculitis and heart

disease $=1$ ), lost to

fallow up (1), unkown

(1). 5 year

survival $=62.5 \%$

Alive and symptom free at 108 months

Patent Died due to the

laryneal cancer at 2

months

Alive and symptom free at 10 months

Alive and no change in pre-operative neurological deficit at 36 months

Full median sternotomy with anterior neck dissection

$\begin{array}{lccccl}\begin{array}{l}\text { lkonomidis } \\ \text { [36] }\end{array} & 2004 & 1: 0 & 7 & 0 & \text { Persistent arm swelling } \\ \text { Takaba [37] } & 2003 & 1: 0 & 20 & - & - \\ \text { Kasashima [38] } & 2000 & 1: 0 & 34 & 0 & \text { Right hemianopia } \\ & & & & & \\ & & & & & \\ \text { Tominage [7] } & 1988 & - & - & - & - \\ \begin{array}{l}\text { Schumacher } \\ \text { [39] }\end{array} & 1979 & 1: 0 & 14 & 0 & \text { Respiratory dysfunction } \\ & & & & & \\ & & & & & \\ \text { Cook [40] } & 1960 & 1: 0 & - & 1 & - \\ & & 1: 0 & 70 & 0 & \text { Infection } \\ \text { Kirby [8] } & 1953 & 1: 0 & 17 & 0 & \text { Paralysis of left arm }\end{array}$

Patent

Patent Alive and symptom

free at 12 months

Alive, right upper

quadrantic hemianopia

and right facial

anhidrosis on day 34

Alive, right voca

paralysis and

hoarseness persisted

dysphagia relieved at 9

months 
Table 1 Summary of observed short and long-term complications (Continued)

Thoracotomy

Cook [40]

1960

$1: 0$

0

Yang [41] $\quad 2009 \quad 1: 0$

Butman [42] $1983 \quad 1: 0$

Unspecified

Gordon-Taylor 1950

[43]

Brain stem/cerebellar infarct

19 Hemiplegia (2), cerebral symptoms (2), haemorrhage (4),

uraemia (1), Respiratory

dysfunction/failure (2),

pneumonia (1), mediastinitis (1)

infection (2), reintervention (1)
Obstructed=1 Paresis (1), cardiac breakdown (1),

haemorrhage (2), persistent

pulsation (1), rupture of

aneurysm (1), ligature cut

through aorta (1), pneumonia (1)

nephritis (1), recurrence (2)
Alive and symptom

free at 55 months.

Imrovement of

aneurysm

10 deaths 

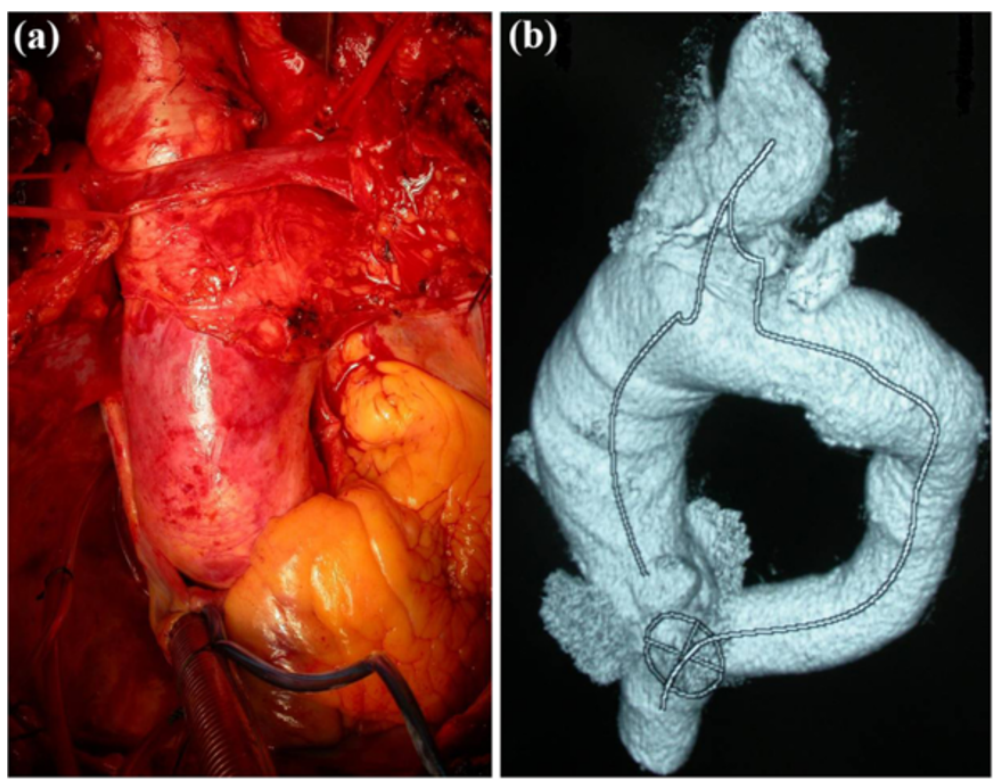

Figure 1 (a) Intra-operative finding of a large IA aneurysm extending into the aortic arch (b) Pre-operative 3D CT reconstruction of the aneurysmal segment.

tomographic angiogram visualized a degenerative aneurysm of the ascending aorta $(5.5 \mathrm{~cm})$, proximal arch $(4.2 \mathrm{~cm})$ and innominate artery $(4.6 \mathrm{~cm})$ (Figure 1$)$.

Under general anaesthesia, median sternotomy was performed extended into the right neck along the medial edge of the sternocleidomastoid. A second left subclavicular incision was made to expose the left axillary artery. Following systemic heparinization, cardiopulmonary bypass $(\mathrm{CPB})$ was instituted with an arterial cannula introduced in the left axillary artery and a two-stage venous cannula introduced into the right atrium, maintaining a flow rate between 2.2 and $2.4 \mathrm{~L} . \mathrm{min}^{-1} . \mathrm{m}^{-2}$ Upon cardiac fibrillation, the ascending aorta was cross-clamped and resected above the coronary ostia at the level of the sinotubular junction. Myocardial arrest was achieved using cold crystalloid cardioplegia $\left(25 \mathrm{ml} . \mathrm{kg}^{-1}\right)$.
A four-limbed $(28 \times 10 \times 8 \times 8 \times 10 \mathrm{~mm})$ Dacron aortic arch graft was prepared and anastomosed proximally to the aortic sinotubular junction with external Teflon strip reinforcement. At a target bladder temperature of $26^{\circ} \mathrm{C}$, the patient was placed in the Trendelenburg position; CPB flow arrested, and the residual ascending aorta and proximal arch were resected preserving the ostia of the IA, left common carotid (LCCA) and left subclavian (LSA) arteries. The aneurysmatic IA was completely resected from its origin in the arch until its distal bifurcation to the right subclavian (RSA) and right common carotid (RCCA) arteries. Unilateral antegrade selective cerebral perfusion $(\mathrm{ASCP}=10 \mathrm{ml} / \mathrm{kg} / \mathrm{min}$, maintenance radial pressure $50 \mathrm{mmHg}$ ) was instituted via a cerebral perfusion catheter to the LCCA and placing soft clamps to the RSA, RCCA and LSA. Cerebral monitoring was

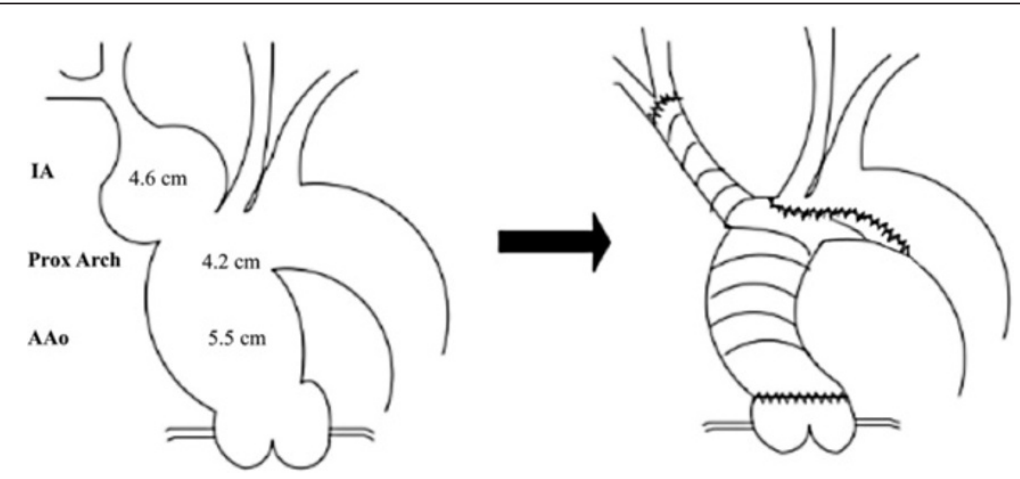

Figure 2 Schematic demonstrating pre-operative anatomy and surgical repair. 
achieved by means of transcutaneous cerebral oximetry and electroencephalogram.

The Dacron graft was trimmed and the two distal side limbs $(8 \mathrm{~mm})$ ligated. The distal end was anastomosed in a hemiarch fashion to the aortic arch proximal to the origin of LCCA and reinforced with external Teflon strips. The side branch of the graft was then anastomosed in an end-to-end fashion to the distal IA. After systematic de-airing, the distal anastomosis to the arch was completed, and systemic perfusion and rewarming commenced (Figures 2 and 3).

The CPB time was 110 minutes, ASCP time $45 \mathrm{mi}-$ nutes, lower body circulatory arrest time 38 minutes and myocardial ischemic time 85 minutes. The patient was extubated 12 hours after surgery with a total ITU stay of 2 days. The post-operative course was unremarkable. Repeat CT three months after surgery and showed an excellent result.

\section{Conclusions}

Since its first description by Valentine Mott in 1818, significant advances have been made in the surgical repair of innominate artery aneurysms. Most attempts in 19th and the beginning of 20th century were limited to ligation of the aneurysm, resulting in mortality rates as high as $30-78 \%$ [5]. Although the method described by Kimura in 1908 involving triple ligation and excision of the aneurysm was technically successful [35], cerebral injury following the ligation of the right common carotid was a serious complication. It was not until 1952, when Kirby and Johnson [38] had reported successful resection of IA aneurysm and reconstruction of circulation to RCCA by end-to-end anastomosis. Utilization of bifur- cated aortic homograft by DeBakey and Crawford in 1956 [42] and introduction of the bifurcated Dacron graft by Hejhal et al. [43] in 1965 were milestones in reducing the mortality to recently observed levels of $5 \%$ [3]. However, operative mortality rate of emergency operations are still being reported as 50\% [3], emphasising the need for early elective repair where possible.

Today the commonest surgical approaches to the IA include median hemisternotomy combined with right anterior thoracotomy in the 3rd intercostal space and the right supraclavicular fossa, median sternotomy with extension along the medial border the right sternocleidomastoid muscle and the more recently reported cervical approach (Table 1).

Although employed less frequently than open surgical repair, endovascular, minimal access cervical or hemisternotomy techniques have more recently been associated with fewer short-term complications, shorter hospital stay, comparable graft patency and similar short- and long- term mortality to open surgery (Table 1). However despite these potential benefits, careful patient selection is needed and long-term outcome data remains lacking. Endovascular treatments can also be challenging in cases of bovine arch morphology [16], where the aneurysmal neck is inadequate for attachment of the graft or when the distal innominate artery is involved [7,11]. Furthermore, covered endovascular stents may require long-term antiplatelet therapy and a closed approach presents diagnostic difficulty in ruling out any malignant processes underlying aneurysm formation [18].

This case demonstrates the safe application of median sternotomy with extension to the right anterior neck to perform open repair of a large, complex aneurysm of the
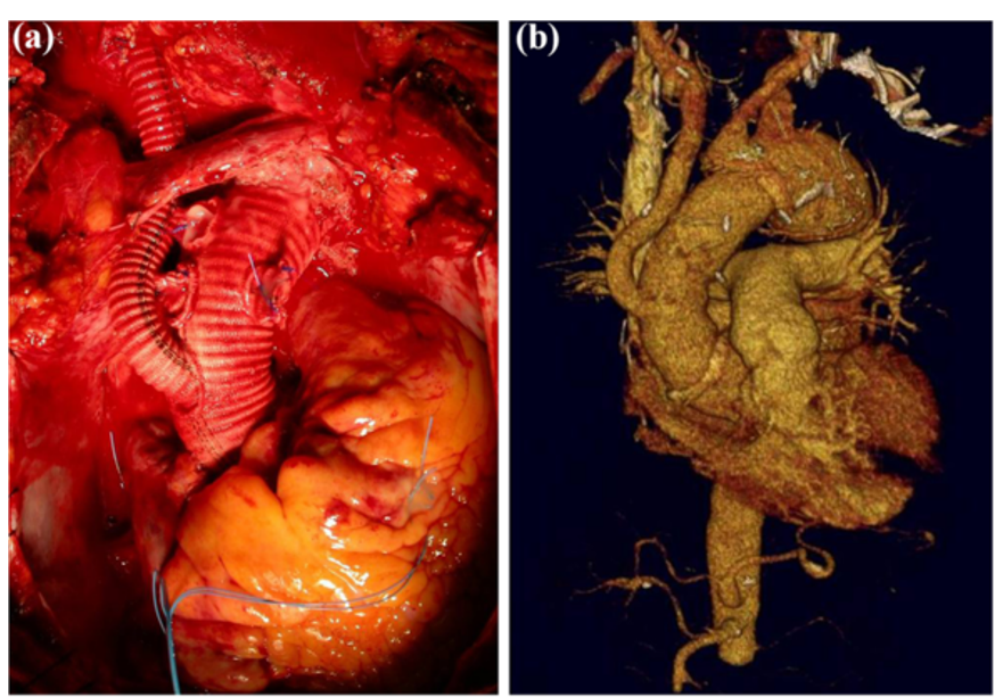

Figure 3 Post operative images demonstrating (a) Final open surgical repair (b) 3D CT reconstruction demonstrating in situ graft reconstruction. 
IA involving the aortic arch. Although open repair carries a relatively higher short-term post-operative morbidity (Table 1), improvement in surgical techniques over the course of the last century has facilitated excellent long-term results. However, the increasing use of minimally invasive strategies presents an emerging alternative in the surgical treatment of these patients. The heterogeneous nature of multiple small studies with a lack of large multi-centre studies and late follow up however limits the data currently available. Further research is therefore required to assess both the long-term patency and mortality associated with minimally invasive surgical approaches.

\section{Consent}

Written informed consent was obtained from the patient for publication of this Case report and any accompanying images. A copy of the written consent is available for review by the Editor-in-Chief of this journal.

\section{Abbreviations \\ IA: Innominate artery; CPB: Cardiopulmonary bypass; LCCA: Left common carotid artery; LSA: Left subclavian artery; RSA: Right subclavian artery; RCCA: Right common carotid artery; ASCP: Antegrade selective cerebral perfusion.}

\section{Competing interests}

There are no financial or non-financial competing interests.

\section{Authors' contributions}

JK, VA, DT and CC carried out the surgical procedure, participated in provision of clinical information and reviewed the manuscript. ES and LH performed the literature review and drafted the manuscript with supervision and assistance from HA and TA. LH, HA and TA finalized the manuscript. All authors read and approved the final manuscript.

\section{Author details}

'Department of Surgery and Cancer, Imperial College London, London, UK. ${ }^{2}$ Second Department of Cardiac Surgery, Evangelismos General Hospital Athens, Athens, Greece. ${ }^{3}$ Department of Surgery and Cancer, Imperial College London, 10th floor QEQM Building, St. Mary's Hospital, Praed Street, London W2 1NY, UK.

Received: 29 April 2013 Accepted: 31 May 2013

Published: 1 June 2013

\section{References}

1. Stolf NA, Bittencourt D, Verginelli G, Zerbini EJ: Surgical treatment of ruptured aneurysms of the innominate artery. Ann Thorac Surg 1983, 35(4):394-399.

2. Cury M, Greenberg RK, Morales JP, Mohabbat W, Hernandez AV: Supra-aortic vessels aneurysms: diagnosis and prompt intervention. J Vasc Surg 2009, 49(1):4-10.

3. Bower TC, Pairolero PC, Hallett JW Jr, Toomey BJ, Gloviczki P, Cherry KJ Jr: Brachiocephalic aneurysm: the case for early recognition and repair. Ann Vasc Surg 1991, 5(2):125-132.

4. Cherry K: Treatment of extracranial, carotid, innominate, subclavian and axillary aneurysms. In Mastery of vascular and endovascular surgery: An illustrated review. Edited by Zelenock GB, Huber TS, Messina LM, Lumsden AB, Moneta GL. Philadelphia, Pa: Lippincott, Williams \& Wilkins; 2006:79-84.

5. Kieffer E, Chiche L, Koskas F, Bahnini A: Aneurysms of the innominate artery: surgical treatment of 27 patients. J Vasc Surg 2001, 34(2):222-228.

6. Kraus TW, Paetz B, Richter GM, Allenberg JR: The isolated posttraumatic aneurysm of the brachiocephalic artery after blunt thoracic contusion. Ann Vasc Surg 1993, 7(3):275-281.
7. Angiletta D, Marinazzo D, Guido G, Fullone M, Pulli R, Regina G: Eight-year follow-up of endovascular repair of a brachiocephalic trunk aneurysm due to Takayasu\&apos;s arteritis. J Vasc Surg 2012, 56(2):504-507.

8. Taha MM, Nakahara I, Higashi T, Iwamuro Y, Watanabe Y, Taki W Interventional neuroradiological techniques for the treatment of aneurysms of the supra-aortic extracranial arteries. Neurol Med Chir 2010, 50(4):275-280

9. Puech-Leão $P$, Orra HA: Endovascular repair of an innominate artery true aneurysm. J Endovasc Ther 2001, 8(4):429-432.

10. Park JH, Chung JW, Joh JH, Song SY, Shin SJ: Aortic and arterial aneurysms in behçet disease: management with stent-grafts- initial experience. Radiology 2001, 220:745-750.

11. Melissano G, Civilini E, Marrocco-Trischitta MM, Chiesa R: Hybrid endovascular and off-pump open surgical treatment for synchronous aneurysms of the aortic arch, brachiocephalictrunk, and abdominal aorta. Tex Hear Inst J 2004, 31(3):283-287.

12. Takach TJ, Lalka SG: Innominate artery aneurysm: axial reconstruction via a cervical approach. J Vasc Surg 2007, 46(6):1267-1269.

13. MacLean AA, Vricella LA, Freischlag JA: Innominate artery aneurysm. Eur J Cardiothorac Surg 2007, 32(5):803.

14. Mori K, Kasuga C, Nakao Y, Yamamoto T, Maeda M: Intracranial pseudoaneurysm due to rupture of a saccular aneurysm mimicking a large partially thrombosed aneurysm ("ghost aneurysm"): radiological findings and therapeutic implications in two cases. Neurosurg Rev 2004, 27(4):289-293.

15. Lane JD, Peirce EC: Endoaneurysmorrhaphy for spontaneous innominate artery aneurysm; report of a case with cure and an important diagnostic complication. Surgery 1951, 30(4):709-717.

16. Constenla I, Alvarez B, Yugueros X, Fernandez E, Bofill R, Matas M: Innominate artery aneurysm with hemoptysis and airway compression in a patient with bovine aortic arch. J Vasc Surg 2012, 56(3):822-825.

17. Oswal A, Mehra A, Karbhase J, Johari A, Karatela R, Shivdasani B: Combined resection of coronary and innominate artery aneurysms. J Card Surg 2011, 26(3):319-321.

18. Lu C-Y, Lu M-S, Huang Y-K, Tsai F-C, Lin PJ: Innominate artery aneurysm as presentation of angiosarcoma. Surgery 2011, 149(4):593-594.

19. Yuan S-M, Tager S: Penetrating atherosclerotic ulcer aneurysm of the innominate artery. VASA Zeitschrift für Gefässkrankheiten 2009, 38(3):263-266.

20. Da Col U, Koukoulis G, Di Bella I, Ramoni E, Ragni T: Surgical treatment of ascending aorta and innominate artery trunk aneurysm with displaced brachiocephalic vessels. J Cardiovasc Med (Hagerstown) 2007, 8(10):852-854

21. Oruganti SS, Mishra RC: Traumatic giant true aneurysm of the brachiocephalic artery. Asian Cardiovasc Thorac Ann 2006, 14(4):352-353.

22. Saito A, Shiono M, Yamamoto T, Inoue T, Hata M, Sezai A, lida M, Niino T, Hattori T, Negishi N, Sezai Y: Surgical treatment for innominate artery aneurysm with a coronary pulmonary artery fistula: a case report. Ann Thorac Cardiovasc Surg 2005, 11(1):55-58.

23. Chiappini B, Arpesella G, Barbara C, Pierangeli A: Delayed post-traumatic aneurysms of aorta, carotid and innominate arteries. European journal of cardio-thoracic surgery 2001, 20(6):1246-1248.

24. Guibaud JP, Laborde MN, Dubrez J, Elia N, Remes J, Rosato F, Roques X, Baudet E: Surgical repair of an aneurysm of the innominate artery with fistulization into the trachea. Ann Vasc Surg 2001, 15(3):412-414.

25. Najafi $H$, Overman D, Kavinsky CJ: An unusual combination of cardiovascular surgical disorders. Ann Thorac Surg 1999, 67(1):241-244.

26. Villegas-Cabello O, Cooley DA: Aneurysm of the innominate artery with aberrant origin of the left carotid artery. Case report. Tex Hear Inst J 1996, 23(4):298-300.

27. Adkins MS, Gaines WE, Laub GW, Anderson WA, Fernandez J, McGrath LB: Management of an innominate artery aneurysm during an open heart operation. Ann Thorac Surg 1993, 56(2):377-379.

28. Thomas TV: Intrathoracic aneurysms of the innominate and subclavian arteries. J Thorac Cardiovasc Surg 1972, 63(3):461-471.

29. Ketonen P, Meurala H, Harjola PT, Mattila S, Ketonen L: Management of arteriosclerotic aneurysms of the innominate and subclavian arteries. Scand J Thorac Cardiovasc Surg 1983, 17(2):129-133.

30. Murray GF, Brawley RK, Gott VL: Reconstruction of the innominate artery by means of a temporary heparin-coated shunt bypass. $J$ Thorac Cardiovasc Surg 1971, 62(1):34-41.

31. Zintel HA, Risbeck EC: Aneurysm of the bifurcation of the innominate artery. Successful excision and restoration of the carotid artery. Am J Surg 1960, 99:929-933 
32. Ikonomidis JS, Kim PY, Crawford FA: Repair of aortic arch coarctation and innominate artery aneurysm with branched Dacron graft. J Thorac Cardiovasc Surg 2004, 127(2):579-581.

33. Takaba K, Aota M, Koike H, Konishi Y: Surgical treatment for intrathoracic aneurysm of the innominate artery in an 83-year-old asymptomatic woman. Jpn J Thorac Cardiovasc Surg 2004, 52(4):194-197.

34. Kasashima F, Urayama $H$, Ohtake $H$, Watanabe $Y$ : Intrathoracic aneurysm of the innominate and right subclavian arteries: report of a case. Surg Today 2001, 31(1):51-54.

35. Tominaga R, Tanaka J, Kawachi Y, Yoshitoshi M, Kohno H, Shiki K, Tokunaga K, Takahashi S: Surgical treatment of respiratory insufficiency due to tracheobronchial compression by aneurysms of the ascending aorta and innominate artery. J Cardiovasc Surg 1988, 29(4):413-417.

36. Schumacher PD, Wright CB: Management of of arteriosclerotic aneurysm of the innominate artery. Surgery 1979, 85(5):489-495.

37. Cook J: A report on three cases of innominate aneurysm. J R Coll Surg Edinb 1960, 5:298-303.

38. Kirby CK, Johnson J: Innominate artery aneurysm treated by resection and end-to-end anastomosis. Surgery 1953, 33(4):562-566.

39. Yang G, Thompson D, Warren A: Late-appearing brachiocephalic aneurysm: an atypical vascular sequella of Kawasaki disease. Pediatr Cardiol 2009, 30(2):197-199.

40. Butman S, Gardin JM, Knoll M: Innominate artery aneurysm with thrombus: detection by two-dimensional echocardiography. J Am Coll Cardiol 1983, 2(2):387-390.

41. Gordon-Taylor G: The surgery of the innominate artery, with special reference to aneurysm. Br J Surg 1950, 37(148):377-404.

42. De Bakey ME, Crawford ES: Resection and homograft replacement of innominate and carotid arteries with use of shunt to maintain circulation. Surg Gynecol Obstet 1957, 105(2):129-135.

43. Hejhal L, Firt P, Michal V, Hejnal J: Some interesting case reports in the field of reconstructive vascular surgery. J Cardiovasc Surg 1965, 6(5):409-415.

doi:10.1186/1749-8090-8-141

Cite this article as: Soylu et al.: Surgical treatment of innominate artery and aortic aneurysm: a case report and review of the literature. Journal of Cardiothoracic Surgery 2013 8:141.

\section{Submit your next manuscript to BioMed Central and take full advantage of:}

- Convenient online submission

- Thorough peer review

- No space constraints or color figure charges

- Immediate publication on acceptance

- Inclusion in PubMed, CAS, Scopus and Google Scholar

- Research which is freely available for redistribution 